\title{
Effect of Some Weed Control Treatments on Potato (Solanum tuberosum, L) Crop
}

\author{
${ }^{1}$ Sharshar, A. A. H, ${ }^{1}$ El-Hassanein, E. Hassanein, ${ }^{2}$ Omayma S. shaltout, \\ ${ }^{2}$ Mona M. Yousry, ${ }^{2}$ Ahmad M. El-Gamal \\ ${ }^{1}$ Agricultural Research Center, Weed Research Central Laboratory, Egypt. \\ ${ }^{2}$ Faculty of agriculture, Saba-Basha, Alexandria University, Egypt. \\ E-mail address for correspondence: alysharshar@yahoo.com
}

\begin{abstract}
Two field experiments were carried out at the Experimental Farm, of Sakha Agriculture Research Station, Agriculture Research Centre, Kafr El-sheikh Governorate which is clay soil. These experiments were conducted to study the effect of some weeds control treatments on weeds and potato crop, during the above mentioned dates 2011/12 and 2012/13 winter seasons. Each experiment comprised twelve treatments which were, 1- Sencor $70 \%$ WP (metribuzin $300 \mathrm{~g} / \mathrm{Fed}$.), which applied at 5\% emergence of potato, 2- Gesagard $50 \% \mathrm{SC}$ (prometryn $1.25 \mathrm{~L} /$ Fed.), applied at $5 \%$ emergence of potato, 3- Stomp 50\% EC (pendimethalin 1.7 L/Fed.), applied after planting (AP) and before irrigation, 4- Amex 48\% EC (butralin 2.5 L/Fed.), applied post planting, 5-Fusilade forte $15 \%$ EC (fluazifop-p-butyl $1.4 \mathrm{~L} /$ Fed.), applied at 30 days after planting (DAP), 6- Sencor followed by Fusilade forte $(300 \mathrm{~g} / 1.4 \mathrm{~L} / \mathrm{Fed}$.), 7 Gesagard followed by Fusilade forte (1.25/1.4 L/Fed.), 8- Stomp followed by Fusilade forte 1.7/1.4 L/Fed, 9- Amex followed by Fusilade forte 2.5/1.4 L/Fed., 10- hand hoeing twice at 45 and 60 DAP, 11- hand hoeing thrice at 45, 60 and 75 DAP, and 12- Untreated control.
\end{abstract}

The results of this obtained showed that the best treatments for controlling weed in potato were hand hoeing twice, hand hoeing thrice and herbicidal combination of Sencor $300 \mathrm{~g} / \mathrm{Fed}$. + Fusilade forte $1.4 \mathrm{~L} / \mathrm{Fed}$. for controlling annual grassy and broadleaved weeds were recorded as of $87.9,95.6,81.5 \%$ total weeds control in the 2011/12 and 2012/13 winter seasons. Moreover, these treatments increased the number of tuber, average weight of tuber, number of tuber $/ 10 \mathrm{~kg}$, plant height $(\mathrm{cm})$, number of main stems, tuber grading index, tuber shape index, tuber dry matter, starch \% and tuber specific gravity compared with untreated check during both seasons of the study.

The research showed that the best treatments to control weeds associated with the potato plants to get the highest yield and quality of potato tubers are hoeing twice or thrice, and four sequenced treatments of Sencor, Stomp, Gesagard and Amex that followed by Fusilade forte for each.

Key words: weed, control, potato, herbicides.

Abbreviations least: $\mathrm{Fed}=\mathrm{Feddan}, \mathrm{AP}=$ after planting, $\mathrm{DAP}=$ days after planting. $\mathrm{V}=\mathrm{V}$ olume $W=$ Weight

\section{INTRODUCTION}

Potato (Solanum tuberosum L.) belongs to family Solanaceae, as one of the most important vegetables crops for local consumption, processing and exportation in Egypt. The cultivated area in the whole season of 2013 was 381379 fed, produced 4265178 tons, by an average 11.18 ton/Fed. (The yearly book of economic and statistics of ministry of Agric. In Egypt, 2014).Weeds in potato fields not only compete with potato for growth factors, but also act as hosts of insects and fungal diseases that in turn infest potato plants. Weed growth reduces the yield of potato tuber by $50 \%$ as reported by Vincent (2009). The use of herbicides in potato field plays an important role in improving the growth of potato plants and consequently increases the productivity of area unit and decreases the cost of production as compared with hand hoeing. 
Evaluation of herbicides in field crop not only depends on the efficiency of the herbicide to control weeds, but also includes the obtaining of crop growth and high quantity and quality of yield. Panghal et al. (2003) found in his study that (0.5 kg metribuzin/ha and $1 \mathrm{~kg}$ pendimethalin/ha 7, 14 or 21 DAP), significantly controlled weeds compared with untreated check. The highest tuber yield was recorded with the application of metribuzin. Arora et al. (2009) found that the highest yield of potato tubers was recorded in plots treated with prometryn $(0.1$ $\mathrm{kg} / \mathrm{ha} P E)$, followed with pendimethalin $(1.0 \mathrm{~K} / \mathrm{ha} P E)$, metribuzin $(0.5 \mathrm{~kg} / \mathrm{ha} P E)$ and two hand weeding. No residual activity of herbicides applied to potato was found in post harvest soil. However the objectives of the present study aimed to increase potato yield production and its quality through finding suitable herbicides as alternative to hand hoeing for controlling weeds in potato fields.

\section{MATERIALS AND METHODS}

A local certified "Spunta" potato seed tubers was planted during the two successive winter seasons of 2011/2012 and 2012/2013. The experiments were conducted in a clay soil at Sakha experimental farm, Agricultural Research Station, Kafr El-Sheikh Governorate. The planting was done on October $23^{\text {rd }}$ and $25^{\text {Th }}$, respectively, in clay soil Table (1). The experimental unit consisted of five rows, $0.7 \mathrm{~m}$ wide and $6.00 \mathrm{~m}$ long, making an area of $21 \mathrm{~m}^{2}$. The hills were at $25 \mathrm{~cm}$ apart. Each plot contained 120 whole tubers. Harvesting was accomplished 120 days from planting. All the agricultural practices for potato production were carried out as common in this area.

Table (1): Physical and chemical analysis of the experimental soil at $(30 \mathrm{~cm})$ depth in 2011/12 and 2012/13 seasons.

\begin{tabular}{|c|c|c|}
\hline Characteristics & 2011/12 season & $2012 / 13$ season \\
\hline \multicolumn{3}{|l|}{ Physical Properties } \\
\hline Clay \% & 49.24 & 50.93 \\
\hline Silt \% & 31.93 & 32.63 \\
\hline Sand \% & 19.83 & 16.44 \\
\hline Soil texture & Clay & Clay \\
\hline \multicolumn{3}{|l|}{ Chemical Properties } \\
\hline $\mathrm{pH}(1: 2.5)$ & 8.14 & 8.11 \\
\hline $\mathrm{EC}\left(\mathrm{dSm}^{-1}\right)(1: 5)$ & 2.90 & 3.20 \\
\hline $\mathrm{CaCO}_{3}, \%$ & 26.33 & 25.93 \\
\hline Organic matter, \% & 0.53 & 0.55 \\
\hline Total nitrogen,\% & 0.034 & 0.03 \\
\hline \multicolumn{3}{|c|}{ Soluble cations (meq/100 g soil) } \\
\hline $\mathrm{Ca}^{++}$ & 3.34 & 3.50 \\
\hline $\mathrm{Mg}^{++}$ & 3.80 & 4.46 \\
\hline $\mathrm{Na}^{+}$ & 7.66 & 8.00 \\
\hline $\mathrm{K}^{+}$ & 0.44 & 0.66 \\
\hline \multicolumn{3}{|c|}{ Soluble anions (meq/100 g soil) } \\
\hline $\mathrm{HCO}_{3}^{-}$ & 6.83 & 7.50 \\
\hline $\mathrm{Cl}^{-}$ & 6.60 & 7.46 \\
\hline $\mathrm{SO}={ }_{4}$ & 0.33 & 0.42 \\
\hline
\end{tabular}


To study the effect of eleven treatments of weeds control plus the untreated check on weeds in potato fields, plant growth, potato yield and quality, the following treatments were applied as follows:

1- Sencor $70 \%$ WP (metribuzin $300 \mathrm{~g} / F e d$.), applied at 5\% emergence of potato,. 2- Gesagard $50 \%$ SC (prometryn $1.25 \mathrm{~L} / \mathrm{Fed}$.), applied at 5\% emergence of potato,. 3-Stomp 50\% EC (pendimethalin $1.7 \mathrm{~L} / \mathrm{Fed}$.), applied AP and before irrigation., 4- Amex 48\% EC (butralin 2.5 L/Fed.), applied AP and before irrigation., 5- Fusilade forte $15 \%$ EC (fluazifop-p-butyl 1.4 L/Fed.), applied at 30 DAP., 6- Sencor flowed by Fusilade forte at the rate $(300 \mathrm{~g} / 1.4$ L/Fed.)., 7- Gesagard flowed by Fusilade forte (1.25 L/1.4 I / Fed.)., 8- Stomp flowed by Fusilade forte (1.7 I / 1.4 I / Fed.)., 9- Amex flowed by Fusilade forte (2.5 I/1.4 I / Fed.)., 10- Hand hoeing twice at 45 and 60 DAP. 11- Hand hoeing thrice at 45, 60 and 75 DAP. and 12- Untreated control. The herbicides were applied by using knapsack sprayer $\mathrm{CP}_{3}$ with volume of $200 \mathrm{~L}$ of water/Fed.

\section{The following measurements were recorded:}

-Weed characters: Weeds were hand pulled at random from one square meter in each plot at 60 and 90 DAP. The weeds were identified into species and classified to annual broad-leaved weeds, narrow-leaved and total weeds. The fresh weights of each species were determined as $\left(\mathrm{g} / \mathrm{m}^{2}\right)$.

-Vegetative growth and yield parameters: Ten whole plant samples per plot were randomly used, 100 DAP, for the determination of the vegetative growth parameters (plant height $(\mathrm{cm})$, number of main stems and total chlorophyll percentage (mg/100g F.W.), which was determined using the fourth top leaves after 80 and 100 days from planting according to Wettstein (1957) method:

○ Chlorophyll (a) $\mathrm{mg} / \mathrm{g}=10.3(\mathrm{O} . \mathrm{D})_{663}-0.918$ (O.D) $644 \times \frac{\mathrm{v}}{\mathrm{w}}$

○ Chlorophyll (b) mg/g =19.7(O.D) $644-3.87(\text { O.D) } 663)_{x} \frac{v}{w}$

A random ten hills were used to calculate the average tuber weight (g), average tuber number. Number of tubers per $10 \mathrm{Kg}$ was determined using a random sample of $10 \mathrm{~kg}$ of tubers from each treatment and then counted. The accepted category to potato processing is that count 72-112 tubers in such treatment, Frito Lay Company (1999). Tuber yield (ton/Fed.) was recorded as the total weight of all harvested tubers per plot and converted into tons per Fed.

-Physical characteristics: Random samples of 10 tubers per treatment were randomly used to measure the physical characteristics of the tubers, tuber length and diameter were measured to calculate the tuber shape index by dividing the length by the width, as reported by Winiger and Ludwing (1974). Tuber specific gravity was determined by a certain weight of tubers for each treatment in the air and secondly under water, then the specific gravity was computed as described by Dinesh et al. (2005). Tuber grading index was computed as follows, potatoes were graded into three categories according to its size i.e., large size (more than $60 \mathrm{~mm}$ ), medium size $(40-60 \mathrm{~mm})$ and small size $(28-40 \mathrm{~mm})$. So, both tuber specific gravity and tuber grading index were calculated according to the following equations: 
○ Tuber specific gravity = Tuber's weight in air/(Tuber's weight in air Tuber's weight in water)

- Tuber grading index $=1 \times$ weight of small size $)+(2 \times$ weight of medium size $)+(3 \times$ weight of large size $)$.

Tuber quality: Random samples of 10 tubers per treatment used to determine the following tuber quality characters:

1. Tuber dry matter \%: Was carried out by weighing a certain weight of fresh tubers and then dried (Haase, 2003).

$\circ$ Dry matter $\%=$ Dry weight $/$ Fresh weight $\times 100$

2. Determination of starch \%: Tuber starch percentage (\%) was determined using a sample of $1 \mathrm{~g}$ of dry weight of tuber, according to the method described in A.O.A.C. (1970).

The used experimental layout of the experiments was arranged in a randomized complete blocks design (R.C.B.D), with four replicates. The twelve treatments of weed control were applied. The data statistically analyzed using analysis of variance method as described by Snedecor and Cochran (1980). The mean values of the tested treatments were compared by least significant range (L.S.R.) according to Duncan's Multiple Range Test (Duncan, 1955) at $p$ $=0.05$ level of probability.

\section{RESULTS AND DISCUSSION}

\section{Weed characters}

\subsection{Effect of weed control treatments on fresh weight of broad-leaved weeds $\left(\mathrm{g} / \mathrm{m}^{2}\right)$ :}

All weed control treatments significantly decreased the fresh weight of broad leaved weeds as compared with untreated check (Table, 2). The highest broad-leaved herbs reduction \% was obtained by applying hand hoeing twice, hand hoeing thrice, Sencor and Gesagard as compared with the untreated check at 60 DAP in 2011/12 winter season, while the results in 2012/13 winter season showed that applying Sencor gave the best result in controlling weeds followed by hand hoeing thrice, both sequenced herbicides of Sencor + Fusilade forte and Stomp + Fusilade forte compared with the untreated check. Applying Sencor, hand hoeing thrice and hand hoeing twice at 90 DAP resulted in the highest reduction in fresh weight of broad leaved weeds, as compared with the untreated check treatment. In 2012/2013 winter season hand hoeing thrice reduced broad leaved weeds followed by hand hoeing twice and the sequence of Stomp + Fusilade forte, compared with the untreated check. These results are in agreement, more or less, with those obtained by Arnold et al. (1991) who found that adding metribuzin to pendimethalin increased weed control. Channappagoudar et al. (2007) and Thomas et al. (2014) found that herbicide mixtures consisted of $1.5 \mathrm{~kg} / \mathrm{ha}$ pendimethalin plus metribuzin, $320 \mathrm{~g}$ ai/ha metribuzin and $1.5 \mathrm{~kg} / \mathrm{ha}$ pendimethalin were also applied alone provided the greatest control of water smartweed.

\subsection{Fresh weight of grassy weeds:}

All weed control treatments decreased the fresh weight of grassy weeds significantly at 60 DAP, as compared with untreated check (Table, 2). The 
highest reductions for grassy weeds were given by applying four sequences: Stomp + Fusilade forte, Amex + Fusilade forte, Fusilade forte, Sencor + Fusilade forte and Gesagard + Fusilade forte. Hand hoeing twice and hand hoeing thrice gave high reductions for the fresh weight of grassy weeds compared with the untreated check. The results in 2012/13 winter season decleared that treated weeds with Fusilade forte, hand hoeing thrice and Gesagard followed by Fusilade forte which resulted in a reduction in the amount of weeds by compared with the untreated check, while applying hand hoeing thrice, Stomp + Fusilade forte and Amex + Fusilade forte sequences at 90 DAP gave reductions in fresh weight of grassy weeds, compared with the untreated check. The data of 2012/13 winter season illustrated that the best results for the reduction of weed fresh weight were given when the weeds were treated with hand hoeing thrice, hand hoeing twice and the sequence of Sencor + Fusilade forte, respectively, compared with the untreated check. These results are in agreement, more or less, with those obtained by El-Mahy (2005) who reported that the post-emergence application of metribuzin and fluazifop-p-butyl resulted in the highest control of grasses and broad leaved weeds infesting potato fields. Arora et al. (2009) and Panghal et al. (2003) found that the metribuzin and pendimethalin applying 14 or 21 DAP significantly controlled weeds compared with untreated check.

\subsection{Fresh weight of total weeds:}

The data of $2011 / 12$ winter season decleared that application of the sequence of Sencor + Fusilade forte, Gesagard and Sencor led to the greatest control of weeds and reduced the fresh weight of total weeds significantly than the untreated ones at 60 DAP in 2011/12 winter season (Table 2). While in 2012/13 winter season applying hand hoeing thrice, Sencor + Fusilade forte (sequenced herbicides) and Gesagard + Fusilade forte (sequenced herbicides) reduced the fresh weight of the total weeds, compared with the untreated check. While the application of hand hoeing thrice, hand hoeing twice and Stomp + Fusilade forte combinations at 90 DAP reduced the fresh weight of total weeds compared with the untreated plot, while the results of 2012/13 winter season showed that hand hoeing thrice, hand hoeing twice and the sequence of Sencor + Fusilade forte caused a reduction in fresh weight of total weeds compared with the untreated check. These results are in accordance, more or less, with those obtained by Mukhopadhyay et al. (2002) as they found that integration of hand weeding with earthing up recorded the least weed population in potato fields. Rana et al. (2004) showed that pendimethalin, hand weeding twice and farmers' practice being, statistically similar and significantly produced higher weedy control. Channappagoudar et al. (2007) found that metribuzin and pendimethalin single application have been found less phytotoxic to potatoes and more efficient in controlling both monocotyledoneae and dicotyledoneae weeds with higher weed control efficiency compared with untreated plot. 


\section{Effect of weed control treatments on Potato growth characteristics}

\subsection{Plant height $(\mathbf{c m})$}

Data presented in Table (3) showed that the application of Sencor + Fusilade forte, Gesagard and Amex + Fusilade forte in 2011/12 winter season increased plant height compared with untreated check. In 2012/13 winter season, treatments of Sencor + Fusilade forte, Gesagard and Sencor produced the tallest plants as compared with untreated plot. These results are in accordance, mor or less, with those obtained by Kumar et al. (2013), who found that application of metribuzin recorded the maximum growth parameters. Gitsopoulos et al. (2014) illustrated that pendimethalin plus metribuzin applied pre-emergence did not cause detrimental effect on growth of potato plants.

\subsection{Number of main stems / plant}

Application of Sencor + Fusilade forte, Stomp + Fusilade forte sequences, hand hoeing twice, hand hoeing thrice, Stomp and Amex, gave the highest values for number of main stems per plant in 2011/12 winter season (Table 3). The obtained results in 2012/13 winter season showed that the treatments of hand hoeing thrice, Stomp + Fusilade forte, Sencor + Fusilade forte, hand hoeing twice, Gesagard + Fusilade forte, Stomp and Amex increased such a character compared with the untreated check (Table, 3). The highest number of main stems was found when Sencor or Stomp was followed by Fusilade in the first season. In the second season, hand hoeing for thrice produced the highest number of main stems per plant. These results are in the same direction with those obtained by Jovovic et al. (2005) who reported found that metribuzin, metribuzin + fluazifopP-butyl (Fusilade super), resulted in a higher number of stems per potato plants compared with untreated check. Kumar et al. (2013) found that application of metribuzin recorded the maximum number of stems per potato plant.

\subsection{Total chlorophyll pigments in potato leaves}

Data presented in Table (3) showed that herbicides treatments increased total chlorophyll, significantly, as a result of applying Sencor, hand hoeing twice and hand hoeing thrice treatments more than the other treatments at 80 DAP in 2011/12 winter season. The obtained results in 2012/13 winter season showed that the chlorophyll content in the treatments of Amex + Fusilade forte sequence and/or Amex alone exceeded than the other treatment at 80 DAP. While herbicide treatments recorded at 100 DAP in 2011/12 winter season where application Sencor, Sencor + Fusilade forte sequence, Fusilade forte, Amex, while 2012/13 winter season, gave the highest percentages of chlorophyll more than the other applications. The preferred herbicides result in more chlorophyll accumulation in potato plant leaves as the weeds were controlled and stopped shading the potato plants. In addition, it afforded more available nutrients and growth factors to potato plants after elimination of weeds. These results are in harmony with those obtained by Channappagoudar et al. (2008) who showed that metribuzin increased the total chlorophyll in potato. 
Table (2): Effect of weed control treatments of potato fields on fresh weight of broad-leaved, grasses and total weeds $\left(\mathrm{g} / \mathrm{m}^{2}\right)$ in Sakha, 2011/2012 and 2012/2013 winter seasons:

\begin{tabular}{|c|c|c|c|c|c|c|c|c|c|c|c|c|}
\hline \multirow{5}{*}{ Treatments } & \multicolumn{6}{|c|}{ 2011/2012 } & \multicolumn{6}{|c|}{ 2012/2013 } \\
\hline & \multicolumn{12}{|c|}{ DAP* $^{*}$} \\
\hline & \multicolumn{3}{|c|}{60} & \multicolumn{3}{|c|}{90} & \multicolumn{3}{|c|}{60} & \multicolumn{3}{|c|}{90} \\
\hline & \multirow{2}{*}{$\begin{array}{c}\text { Broadleaf } \\
\text { weeds }\end{array}$} & \multirow{2}{*}{$\begin{array}{l}\text { Grassy } \\
\text { Weeds }\end{array}$} & \multirow{2}{*}{ Total } & \multirow{2}{*}{$\begin{array}{c}\text { Broadleaf } \\
\text { Weeds }\end{array}$} & \multirow{2}{*}{$\begin{array}{l}\text { Grassy } \\
\text { Weeds }\end{array}$} & \multirow{2}{*}{ Total } & \multirow{2}{*}{$\begin{array}{c}\text { Broadleaf } \\
\text { Weeds }\end{array}$} & \multirow{2}{*}{$\begin{array}{l}\text { Grassy } \\
\text { weeds }\end{array}$} & \multirow{2}{*}{ Total } & \multirow{2}{*}{$\frac{\text { Broadleaf }}{\text { Weeds }}$} & \multirow{2}{*}{$\begin{array}{l}\text { Grassy } \\
\text { weeds }\end{array}$} & \multirow{2}{*}{ Total } \\
\hline & & & & & & & & & & & & \\
\hline Sencor $70 \%$ & $2.1 \mathrm{~g}$ & 45.8 e & $47.9 \mathrm{~h}$ & $15.4 \mathrm{i}$ & $745 b$ & $760.4 d$ & $0 \mathrm{i}$ & $82.7 \mathrm{~b}$ & $82.7 f$ & $652.5 \mathrm{e}$ & $6.6 j$ & $659.1 \mathrm{~g}$ \\
\hline Gesagard $\mathbf{5 0} \%$ & $3.4 \mathrm{~g}$ & $20.2 \mathrm{~g}$ & $23.6 \mathrm{i}$ & $77.8 \mathrm{f}$ & $560 \mathrm{~d}$ & $637.8 \mathrm{f}$ & $31.3 \mathrm{e}$ & $24.5 \mathrm{fg}$ & $55.8 \mathrm{~h}$ & $951.3 \mathrm{c}$ & $75.3 \mathrm{~h}$ & $1026.5 \mathrm{c}$ \\
\hline Stomp $50 \%$ & $28.9 f$ & $36.3 f$ & $65.2 \mathrm{~g}$ & $142.5 \mathrm{e}$ & $502.5 \mathrm{e}$ & 645 ef & $25.1 \mathrm{f}$ & $77.6 \mathrm{c}$ & $102.8 \mathrm{~d}$ & $1025 b$ & $152 \mathrm{~g}$ & $1177 b$ \\
\hline Amex $48 \%$ & $214.8 b$ & $245.5 b$ & $460.3 b$ & $361.9 \mathrm{~b}$ & $690.7 \mathrm{c}$ & $1052.6 b$ & $33 \mathrm{e}$ & $56.2 d$ & $89.1 \mathrm{e}$ & $751.9 d$ & $236.9 \mathrm{e}$ & $988.8 d$ \\
\hline Fusilade forte $15 \%$ & $195.1 \mathrm{c}$ & $3 \mathrm{hi}$ & 198.1d & $361.9 b$ & $511.3 \mathrm{e}$ & $873.2 \mathrm{c}$ & $340.8 \mathrm{~b}$ & $78.0 \mathrm{c}$ & $418.6 \mathrm{~b}$ & $553.5 f$ & $175.3 f$ & $728.8 \mathrm{e}$ \\
\hline Sencor + Fusilade forte & $2.5 \mathrm{~g}$ & $6.6 \mathrm{~h}$ & $9.1 \mathrm{j}$ & $38.8 \mathrm{~g}$ & $262.2 \mathrm{~g}$ & $301 \mathrm{~h}$ & $0.9 \mathrm{i}$ & Oh & $0.9 \mathrm{k}$ & $276.5 \mathrm{~h}$ & $30.5 i$ & $307 \mathrm{i}$ \\
\hline Gesagard + Fusilade forte & $62.1 \mathrm{e}$ & $6.7 \mathrm{~h}$ & $68.8 \mathrm{~g}$ & $366.3 b$ & $293.6 \mathrm{f}$ & 659.9 e & $41.2 d$ & $22 \mathrm{~g}$ & $63.2 \mathrm{~g}$ & $324.3 \mathrm{~g}$ & $401.8 \mathrm{c}$ & $726 \mathrm{e}$ \\
\hline Stomp + Fusilade forte & $63.2 \mathrm{e}$ & $0 \mathrm{i}$ & $63.2 \mathrm{~g}$ & $221.8 \mathrm{c}$ & $93.5 \mathrm{j}$ & $315.3 \mathrm{~h}$ & $5.4 \mathrm{~h}$ & $44.6 \mathrm{e}$ & $50 i$ & $103.8 \mathrm{j}$ & $345 d$ & $448.8 \mathrm{~h}$ \\
\hline Amex + Fusilade forte & $223.4 \mathrm{a}$ & $0.2 \mathrm{i}$ & $223.6 \mathrm{c}$ & $451.8 \mathrm{a}$ & $128.5 \mathrm{i}$ & $580.3 \mathrm{~g}$ & $113.3 \mathrm{c}$ & $23.6 \mathrm{fg}$ & $136.9 \mathrm{c}$ & $127 \mathrm{i}$ & $546.5 b$ & $673.5 f$ \\
\hline Hand hoeing Twice & $0 \mathrm{~g}$ & $84.9 \mathrm{~d}$ & $84.9 f$ & $23.2 \mathrm{~h}$ & $174 \mathrm{~h}$ & $197.2 \mathrm{i}$ & $9.4 \mathrm{~g}$ & $24.7 f$ & $34.1 \mathrm{j}$ & $73.5 \mathrm{k}$ & $9.7 \mathrm{j}$ & $83.2 \mathrm{j}$ \\
\hline Hand hoeing Thrice & $0 \mathrm{~g}$ & $131.1 \mathrm{c}$ & $131.1 \mathrm{e}$ & $20.5 \mathrm{~h}$ & $51.3 \mathrm{k}$ & $71.8 \mathrm{j}$ & $0 \mathrm{i}$ & $\mathrm{Oh}$ & $0 \mathrm{k}$ & 01 & $0 \mathrm{k}$ & $0 \mathrm{k}$ \\
\hline untreated plot & $105.6 d$ & $641.9 a$ & $747.5 a$ & $104.5 d$ & $1525 \mathrm{a}$ & $1629.5 a$ & $399.1 a$ & $824.7 a$ & $1223.7 \mathrm{a}$ & $1443.8 a$ & $2048.5 a$ & $3492.3 a$ \\
\hline
\end{tabular}

Values with the same Alphabetical letter, in a comparable group of means do' not differ from each other significantly according to Duncan's Multiple Range best at 0.05 level of significance.

DAP = Days after planting 
Table (3) Effect of weed control treatments on plant height, number of main stems and chlorophyll concentration in potatoes leaves in Sakha, 2011/2012 and 2012/2013 winter seasons:

\begin{tabular}{|c|c|c|c|c|c|c|c|c|}
\hline \multirow{5}{*}{ Treatments } & \multicolumn{4}{|c|}{$2011 / 2012$} & \multicolumn{4}{|c|}{$2012 / 2013$} \\
\hline & \multirow{3}{*}{$\begin{array}{c}\text { Plant } \\
\text { height }\end{array}$} & \multirow{3}{*}{$\begin{array}{c}\begin{array}{c}\text { Number } \\
\text { of }\end{array} \\
\text { Main } \\
\text { stems/ } \\
\end{array}$} & \multirow{2}{*}{\multicolumn{2}{|c|}{$\begin{array}{l}\text { Total chlorophyll } \\
(\mathrm{mg} / \mathrm{g})\end{array}$}} & \multirow{3}{*}{$\begin{array}{c}\text { Plant } \\
\text { height }\end{array}$} & \multirow{3}{*}{$\begin{array}{c}\begin{array}{c}\text { Number } \\
\text { of }\end{array} \\
\text { Main } \\
\text { stems/ }\end{array}$} & \multirow{2}{*}{\multicolumn{2}{|c|}{$\begin{array}{l}\text { Total chlorophyll } \\
(\mathrm{mg} / \mathrm{g})\end{array}$}} \\
\hline & & & & & & & & \\
\hline & & & chla+b & chla+b & & & chl. $a+b$ & chl. $\mathbf{a}+\mathbf{b}$ \\
\hline & $(\mathrm{cm})$ & Plant & 80 days & 100 days & (cm) & Plant & 80 days & 100 days \\
\hline Sencor , $70 \%$ & $26 \mathrm{e}$ & $1.8 \mathrm{~b}$ & $6.77 \mathrm{a}$ & $3.2 \mathrm{ab}$ & $31.75 \mathrm{bc}$ & $2 a b$ & $6.04 \mathrm{e}$ & $4.38 \mathrm{a}$ \\
\hline Amex, $48 \%$ & $26 \mathrm{e}$ & $2.3 a b$ & 5.75 ef & $3.63 \mathrm{~cd}$ & $29.25 d$ & $2.25 \mathrm{a}$ & $6.39 \mathrm{~b}$ & $3.76 \mathrm{~d}$ \\
\hline Fusilade forte, $15 \%$ & $26 \mathrm{e}$ & $2 a b$ & $5.20 \mathrm{gh}$ & $3.92 \mathrm{bc}$ & $26.25 \mathrm{e}$ & $2 a b$ & $5.62 \mathrm{~h}$ & $3.18 \mathrm{~g}$ \\
\hline Sencor +Fusilade forte & $34.5 a$ & $2.5 \mathrm{a}$ & $5 \mathrm{~h}$ & $4.14 \mathrm{~b}$ & $36.5 a$ & $3 a$ & $5.60 \mathrm{~h}$ & $3.72 \mathrm{e}$ \\
\hline Gesagard + Fusilade forte & $27.3 \mathrm{de}$ & $2 a b$ & $5.59 \mathrm{f}$ & 3.52 de & $30.5 \mathrm{bcd}$ & $2.25 \mathrm{a}$ & $6.28 \mathrm{c}$ & $3.89 \mathrm{~b}$ \\
\hline Stomp + Fusilade forte & $29 \mathrm{bc}$ & $2.5 a$ & $6.09 \mathrm{~d}$ & $3 \mathrm{gh}$ & $29.25 d$ & $3 a$ & $6.30 \mathrm{c}$ & $3.76 \mathrm{~d}$ \\
\hline untreated plot & $22.3 f$ & $1 c$ & $3.95 i$ & $1.88 \mathrm{i}$ & $25.5 e$ & $1 b$ & $5.19 i$ & $2.32 \mathrm{~h}$ \\
\hline
\end{tabular}

Values with the same Alphabetical letter, in a comparable group of means don't differ from each other significantly according to Duncan's Multiple Range best at 0.05 level of probability. 


\section{Effect of weed control treatments on Potato yield and yield component}

\subsection{Number of tubers / plant:}

Data presented in Table (4) showed that the highest number of tubers/plant were obtained from application of hand hoeing thrice, Sencor + Fusilade forte (sequence) and Gesagard than the other treatments in the first seasons. Meanwhile, in the second season, the highest tuber numbers / plant were obtained from the applications of Sencor + Fusilade forte, Gesagard, hand hoeing thrice, hand hoeing twice and the sequence of Gesagard + Fusilade forte. Chemical and mechanical weed of control treatments reduced weed competition and thus afforded more efficient utilization of available environmental resources to potato plants to produce taller plants having more leaves and number of tubers per plant than untreated ones. Such an increase in the number of tubers / plant as a result of weeding potato fields may be related to the increased number of main stems as the weed was eliminated (Table 4). It is well known that as the number of potato main stems increased the number of formed tubers / plant are increased (EL-Gamal, 1989). The highest number of tubers / plant was found by using Gesagard or Sencor followed by Fusilade in both seasons of the study. Kumar et al. (2013) found that application of metribuzin recorded the maximum growth parameters. Thomas et al. (2014) found that herbicide mixtures consisted of pendimethalin plus metribuzin, metribuzin and pendimethalin were also applied alone did not cause detrimental effect on the growing potato plants.

\subsection{Average tuber weight (gm)}

Data in Table (4) express significant impacts for weed control treatments on the average tuber weight were observed as a result of applying the herbicides treatments. In this respect, the herbicides treatments, Sencor followed by Fusilade forte, Stomp followed by Fusilade forte and Amex followed by Fusilade forte gave the highest increases in average tuber weight compared with the untreated check in 2011/12 winter season. The results of 2012/13 winter season, Sencor followed by Fusilade forte, Stomp followed by Fusilade forte and Amex followed by Fusilade forte, caused significant increases in the average of tuber weight compared with the untreated plot. These results are in agreement, more or less, with those obtained by Kumar et al. (2013) and Gitsopoulos et al. (2014) as they found that application of metribuzin recorded the maximum growth parameters (average tuber weight/plant).

\subsection{Number of tubers $/ 10 \mathrm{~kg}$}

Data presented in Table (4) showed that the highest increases in the number of tubers $/ 10 \mathrm{~kg}$ were at harvest resulted from application of the hand hoeing thrice, Stomp followed by Fusilade forte, Sencor followed by Fusilade forte, and hand hoeing twice treatments as over the other treatments in 2011/12 season. The results of 2012/13 winter season appeared that the treatments of Sencor + Fusilade forte, Stomp + Fusilade forte, hand hoeing twice, hand hoeing thrice and Sencor treatments caused increase on number of tubers per $10 \mathrm{~kg}$ although it was in the same acceptable standard range of Frito Lay company (1999) compared with the untreated check. These results are agreed with those obtained by Kumar et al. (2013) who found that application of 
metribuzin $500 \mathrm{~g}$ a.i./ha recorded the maximum growth parameters, yield attributes number of tubers plant and total tuber yield of potato crop. Recently these results confirm the results obtained by Gitsopoulos et al. (2014) as they found that applying pendimethalin $0.5 \mathrm{~kg}$ plus metribuzin $320 \mathrm{~g}$ ai/ha applied pre-emergence, metribuzin and pendimethalin were also applied alone did not cause detrimental effect on growth of potato and marketable tuber yield which generally improved with application of the mixtures when compared with metribuzin $320 \mathrm{~g}$ ai/ha or pendimethalin $0.5 \mathrm{~kg}$ ai/ha applied alone. The processing potato tubers are accepted according to Frito Lay Company (1999) standard $(72-112$ tubers / $10 \mathrm{~kg}$ ). They claimed that when the number is $<72$ / $10 \mathrm{~kg}$, the tubers are big and the possibility of the presence of the hallow heart disorder are high and the produced slices are rejected. In the case of more number of the tubers than 112 tubers / $10 \mathrm{~kg}$, the tubers are small and it will produce small slices of chips, which are rejected.

\subsection{Tuber yield (ton/Fed.)}

Data collected in Table (4) illustrated that the application of Stomp + Fusilade forte (sequence), hand hoeing twice, Sencor + Fusilade forte (sequence) and hand hoeing thrice in 2011/12 winter season gave the highest potato tuber yield (ton / Fed.) and significantly increased the yield than the untreated check, while the results of 2012/13 winter season appeared that the five above treatments, Stomp + Fusilade forte (sequence), hand hoeing twice, hand hoeing thrice, Sencor + Fusilade forte (sequence) and Amex + Fusilade forte (sequence) increased the total yield, compared with the untreated plants.

The increases in potato tuber yield ton/fed. may be taken place due to weed control by herbicide sequences, single herbicides or hoeing than untreated check which might be due to the increases in, number of tubers per plant, average tuber weight, number of tubers per $10 \mathrm{~kg}$ and number of main stems per plant. Moreover, the increases in tuber yield per plant in weed control treatments could be due to the depression of weed growth and minimizing weed competition which improved increased chlorophyll $a, b$ pigment $\%$ and consequently increased carbohydrates syntheses. These results are in agreement, more or less, with those obtained by Rashmi and Kumar (2011) as they found that metribuzin $525 \mathrm{~g}$ ai/ha and hand weeding which gave maximum potato tuber-yield., due to improving growth parameters, yield attributes (number of stolons, plant number of tubers, plant fresh weight, dry weight of tubers, tuberization efficiency and total tuber yield of potato crop) and with results obtained by Mukherjee et al. (2012) who showed that the application of metribuzin (early post-emergence) or pendimethalin (pre-emergence) in ridge planted potato, followed by earthing up at 45 DAP increased tuber yield and profitability. Kumar et al. (2013) stated that application of Metribuzin recorded the maximum growth parameters, yield attributes number of tubers / plant and total yield of potato crop. 
Table (4): Effect of weed control treatments on potato yield and yield components in Sakha, 2011/12 and 2012/13winter seasons.

\begin{tabular}{lcccccccc}
\hline & \multicolumn{4}{c}{$\mathbf{2 0 1 1 / 1 2}$} & \multicolumn{3}{c}{$\mathbf{2 0 1 2 / 1 3}$} \\
\cline { 2 - 9 } Treatments & $\begin{array}{c}\text { Number } \\
\text { of tubers } \\
\text { / plant }\end{array}$ & $\begin{array}{c}\text { Average } \\
\text { tuber } \\
\text { weight } \\
\text { (gm) }\end{array}$ & $\begin{array}{c}\text { Number } \\
\text { of tuber } \\
\text { /10 kg. }\end{array}$ & $\begin{array}{c}\text { Yield } \\
\text { ton / fed. }\end{array}$ & $\begin{array}{c}\text { Number } \\
\text { of tubers } \\
\text { / plant }\end{array}$ & $\begin{array}{c}\text { Average } \\
\text { tuber } \\
\text { weight (g) }\end{array}$ & $\begin{array}{c}\text { Number } \\
\text { of tubers } \\
\text { /10 kg. }\end{array}$ & $\begin{array}{c}\text { Yield } \\
\text { ton / fed. }\end{array}$ \\
\hline Sencor 70\% & $5.5 \mathrm{~cd}$ & $119 \mathrm{~d}$ & $116.3 \mathrm{~b}$ & $11.6 \mathrm{~b}$ & $7 \mathrm{bc}$ & $149.28 \mathrm{c}$ & $121 \mathrm{a}$ & $10.57 \mathrm{c}$ \\
Gesagard 50\% & $7 \mathrm{~b}$ & $94.3 \mathrm{~g}$ & $92.3 \mathrm{~g}$ & $10.8 \mathrm{e}$ & $9 \mathrm{a}$ & $97.58 \mathrm{e}$ & $95.75 \mathrm{~d}$ & $8.79 \mathrm{de}$ \\
Stomp 50\% & $5.75 \mathrm{~cd}$ & $101.2 \mathrm{f}$ & $111.5 \mathrm{c}$ & $10.9 \mathrm{de}$ & $7 \mathrm{bc}$ & $124.7 \mathrm{~d}$ & $113 \mathrm{~b}$ & $11.36 \mathrm{~b}$ \\
Amex 48\% & $5.5 \mathrm{~cd}$ & $100.5 \mathrm{f}$ & $107.3 \mathrm{~d}$ & $11.4 \mathrm{bc}$ & $7 \mathrm{bc}$ & $145.78 \mathrm{c}$ & $112 \mathrm{~b}$ & $9.39 \mathrm{~d}$ \\
Fusilade forte15\% & $5.5 \mathrm{~cd}$ & $122.4 \mathrm{c}$ & $104.3 \mathrm{e}$ & $11.1 \mathrm{~cd}$ & $6.5 \mathrm{~cd}$ & $159.95 \mathrm{~b}$ & $86.75 \mathrm{e}$ & $8.42 \mathrm{e}$ \\
Sencor + Fusilade forte & $7 \mathrm{~b}$ & $134.8 \mathrm{a}$ & $115.8 \mathrm{~b}$ & $12.7 \mathrm{a}$ & $9 \mathrm{a}$ & $168.3 \mathrm{a}$ & $123 \mathrm{a}$ & $12.49 \mathrm{a}$ \\
Gesagard + Fusilade forte & $5.5 \mathrm{~cd}$ & $133.3 \mathrm{ab}$ & $106.3 \mathrm{de}$ & $11.8 \mathrm{~b}$ & $6.25 \mathrm{~d}$ & $158.5 \mathrm{~b}$ & $96.25 \mathrm{~d}$ & $12.04 \mathrm{ab}$ \\
Stomp + Fusilade forte & $6.25 \mathrm{bcd}$ & $134.8 \mathrm{a}$ & $120.3 \mathrm{a}$ & $12.9 \mathrm{a}$ & $7.25 \mathrm{~b}$ & $168.15 \mathrm{a}$ & $122.5 \mathrm{a}$ & $12.72 \mathrm{a}$ \\
Amex + Fusilade forte & $5.5 \mathrm{~cd}$ & $131 \mathrm{~b}$ & $99.8 \mathrm{f}$ & $9.8 \mathrm{f}$ & $7 \mathrm{bc}$ & $164.93 \mathrm{a}$ & $100.75 \mathrm{c}$ & $12.29 \mathrm{a}$ \\
Hand hoeing twice & $6.5 \mathrm{bc}$ & $122.4 \mathrm{c}$ & $115.8 \mathrm{~b}$ & $12.9 \mathrm{a}$ & $6.75 \mathrm{bcd}$ & $149.7 \mathrm{c}$ & $122.5 \mathrm{a}$ & $12.61 \mathrm{a}$ \\
Hand hoeing thrice & $8.5 \mathrm{a}$ & $111.6 \mathrm{e}$ & $121.5 \mathrm{a}$ & $12.6 \mathrm{a}$ & $7.25 \mathrm{~b}$ & $149.15 \mathrm{c}$ & $122.25 \mathrm{a}$ & $12.51 \mathrm{a}$ \\
(untreated) check & $5.25 \mathrm{~d}$ & $84.1 \mathrm{~h}$ & $85 \mathrm{~h}$ & $6.8 \mathrm{~g}$ & $4.25 \mathrm{e}$ & $96.43 \mathrm{e}$ & $86.75 \mathrm{e}$ & $6.47 \mathrm{f}$ \\
\hline
\end{tabular}

Values with the same Alphabetical letter, in a comparable group of means don't differ from each other significantly according to Duncan's Multiple Range best at 0.05 level of probability.

\section{Effect of weed control treatments on potato quality}

\subsection{Tuber grading index}

Data presented in Table (5) showed that all weed control treatments increased tuber grading index significantly as compared with untreated plant. The highest tuber grading index values (means prevailing of the large tubers in the treatment) were obtained by applying hand hoeing thrice, Stomp followed by Fusilade forte, Sencor followed by Fusilade forte, compared with the check treatment in 2011/12 winter season. In winter season of 2012/13 applying Stomp followed by Fusilade forte, Amex followed by Fusilade forte and hand hoeing thrice, Sencor followed by Fusilade forte, and hand hoeing twice gave similar high results, compared with the untreated check. These results are in harmony with those obtained by Salna and Tyla (1996) as they showed that the herbicides Fusilade Super applied only or in mixtures with Sencor increased the mass of medium and big potato tubers. Mircov et al. (2006) found that the application of pendimethalin singly or mixing with metribuzin increased marketable potato yields compared with untreated check. Tuber grading index denote to the more prevailing tuber size in a potato lot. As it increases the prevailing large to medium size are increases and vice versa. This index can easily determine the lot price. 
Table (5). Effect of weed control treatments on potato tuber characteristics, in Sakha station ,2011/12 and 2012/13 winter seasons

\begin{tabular}{|c|c|c|c|c|c|c|c|c|c|c|}
\hline \multirow{4}{*}{ Treatments } & \multicolumn{5}{|c|}{ 2011/2012 } & \multicolumn{5}{|c|}{$2012 / 2013$} \\
\hline & Tuber & Tuber & \multirow{2}{*}{$\begin{array}{c}\text { Dry } \\
\text { matter }\end{array}$} & \multirow{3}{*}{ Starch\% } & Tuber & Tuber & Tuber & \multirow{2}{*}{$\begin{array}{c}\text { Dry } \\
\text { matter }\end{array}$} & \multirow{3}{*}{ Starch\% } & \multirow{3}{*}{$\begin{array}{c}\text { Tuber } \\
\text { specific } \\
\text { gravity }\end{array}$} \\
\hline & grading & Shape & & & Specific & Grading & shape & & & \\
\hline & Index & Index & $\%$ & & Gravity & Index & index & $\%$ & & \\
\hline Sencor $70 \%$ & $24.275 \mathrm{de}$ & $1.71 \mathrm{c}$ & $22.2 \mathrm{a}$ & $86.5 \mathrm{a}$ & $1.06 \mathrm{c}$ & $22.1 \mathrm{e}$ & $1.65 \mathrm{~d}$ & $22.4 \mathrm{a}$ & $85 a$ & $1.038 \mathrm{a}$ \\
\hline Gesagard $50 \%$ & $22.25 \mathrm{~g}$ & $1.89 b$ & $20.2 a b$ & 75.5 de & $1.05 \mathrm{c}$ & $17.91 \mathrm{~g}$ & $1.87 \mathrm{~b}$ & $22.2 \mathrm{a}$ & $84.25 \mathrm{a}$ & $1.03 \mathrm{a}$ \\
\hline Stomp $50 \%$ & $22.675 \mathrm{fg}$ & $1.9 a$ & $19.6 \mathrm{~b}$ & $78.25 \mathrm{c}$ & $1.08 \mathrm{~b}$ & $24.325 d$ & $1.99 \mathrm{a}$ & $21.9 \mathrm{ab}$ & $82.5 \mathrm{a}$ & $1.038 \mathrm{a}$ \\
\hline Amex $48 \%$ & $25.1 \mathrm{~d}$ & $1.46 \mathrm{e}$ & $20 a b$ & $76.65 \mathrm{~d}$ & $1.11 \mathrm{a}$ & $22.123 \mathrm{e}$ & $1.53 \mathrm{e}$ & $19.5 \mathrm{~b}$ & $80 \mathrm{a}$ & $1.023 \mathrm{a}$ \\
\hline Fusilade forte $15 \%$ & $24.55 \mathrm{de}$ & $1.71 \mathrm{c}$ & $19.5 b$ & $84 b$ & $1.06 \mathrm{c}$ & $20.3 f$ & $1.76 \mathrm{c}$ & $22.7 \mathrm{a}$ & $78.25 \mathrm{a}$ & $1.028 \mathrm{a}$ \\
\hline Sencor +Fusilade forte & $30.45 a b$ & $1.49 \mathrm{e}$ & $21.2 \mathrm{a}$ & $85.4 a b$ & $1.11 \mathrm{a}$ & $29.513 b c$ & $1.47 \mathrm{f}$ & $21.5 a b$ & $85 \mathrm{a}$ & $1.048 \mathrm{a}$ \\
\hline Gesagard +Fusilade forte & $29.275 \mathrm{bc}$ & $1.62 d$ & $18.5 \mathrm{~b}$ & $71.37 f$ & $1.05 \mathrm{~cd}$ & $28.395 c$ & $1.62 \mathrm{~d}$ & $21.4 \mathrm{ab}$ & $79.25 \mathrm{a}$ & $1.053 \mathrm{a}$ \\
\hline Stomp + Fusilade forte & $31.275 \mathrm{a}$ & $1.7 \mathrm{c}$ & $20 a b$ & $85.7 \mathrm{a}$ & $1.03 \mathrm{~d}$ & $31.533 \mathrm{a}$ & $1.76 \mathrm{c}$ & $22.6 \mathrm{a}$ & $85 \mathrm{a}$ & $1.035 \mathrm{a}$ \\
\hline Amex + Fusilade forte & 23.65 ef & $1.7 \mathrm{c}$ & $18.5 \mathrm{~b}$ & $75.62 d e$ & $1.04 \mathrm{~cd}$ & $30.875 \mathrm{ab}$ & $1.64 \mathrm{~d}$ & $19.9 \mathrm{~b}$ & $78 \mathrm{a}$ & $1.028 \mathrm{a}$ \\
\hline Hand hoeing Twice & $29 c$ & $1.65 d$ & $19 \mathrm{~b}$ & $74.9 \mathrm{e}$ & $1.11 \mathrm{a}$ & $28.963 \mathrm{c}$ & $1.65 \mathrm{e}$ & $22.5 \mathrm{a}$ & $85 a$ & $1.035 \mathrm{a}$ \\
\hline Hand hoeing Thrice & $31.3 \mathrm{a}$ & $1.64 d$ & $19 \mathrm{~b}$ & $74.57 \mathrm{e}$ & $1.11 \mathrm{a}$ & $29.463 \mathrm{c}$ & $1.77 \mathrm{c}$ & $22.4 \mathrm{a}$ & $83 a$ & $1.03 \mathrm{a}$ \\
\hline (untreated) check & $15.075 \mathrm{~h}$ & $1.2 f$ & $18 \mathrm{c}$ & $70.25 \mathrm{f}$ & $1.01 \mathrm{e}$ & $16.293 \mathrm{~h}$ & $1.2 \mathrm{~g}$ & $17.2 \mathrm{c}$ & $49.5 b$ & $1.01 \mathrm{~b}$ \\
\hline
\end{tabular}

Values with the same Alphabetical letter, in a comparable group of means don't differ from each other significantly according to Duncan's Multiple Range best at 0.05 level of probability. 


\subsection{Tuber shape index}

The data of the tuber shape index character are presented in Table (5). The data decleared that all the tested treatments amended the Spunta tuber shape significantly than the untreated check in both seasons of the study. Kumar et al. (2013) found that application of metribuzin recorded the maximum growth parameters, yield attributes number of tubers / plant and total tuber yield of potato crop. Recently, Gitsopoulos et al. (2014) illustrated that herbicide treatments pendimethalin plus metribuzin applied pre-mergence, metribuzin and pendimethalin were also applied alone did not cause detrimental effect on marketable tuber yield.

\subsection{Tuber dry matter:}

All the tested weed control treatments increased tuber dry matter percentage significantly as compared with untreated plant (Table, 5). The highest dry \% was obtained by applying Sencor, followed by Fusilade forte and Gesagard, compared with the untreated check during 2011/12 season. The results during 2012/13 season appeared that the treatments of hand hoeing thrice, Stomp followed by Fusilade forte, Sencor, Gesagard, scored the highest tuber dry matter \% compared with the untreated check. These results are in going in parallel with those obtained by Arora et al. (2009) as they found the highest tuber dry matter content of potato tuber was recorded in hand weeding treatment while higher dry matter yield was recorded in prometryn, pendimethalin and metribuzin treatments and Kumar et al. (2013) found that application of metribuzin recorded the maximum dry matter of tubers and total tuber yield of potato crop.

\subsection{Starch \%}

Data in Table (5) showed that the highest starch \% presented to Sencor, Stomp followed by Fusilade forte and Sencor sequenced by Fusilade forte scored during 2011/12 season compared with untreated check. These results are in the same trend with those obtained by Channappagouder et al. (2008) as they showed that metribuzin increased total starch content in potato. Arora et al. (2009) found that prometryn increased starch \%. Kheraba et al. (1991) found that metribuzin increased the total carbohydrate content of potato tuber.

\subsection{Specific gravity:}

All tested treatments resulted in increases in tuber specific gravity when compared with the untreated plants (Table 5). The best results were obtained with hand hoeing thrice, hand hoeing twice, Sencor sequenced by Fusilade forte, and Amex compared with the untreated check in 2011/12 winter season. The results of 2012/13 season appeared that the treatments of Gesagard sequenced by Fusilade forte, Sencor sequenced by Fusilade forte, Stomp and Sencor produced the highest values for this character, compared with the untreated check. These results are in accordance with those obtained by Kheraba et al. (1991) as they found that the highest specific gravity was found in potato treated with metribuzin, and the next highest specific gravity was found in potato treated with pendimethalin + hand hoeing. In the contrary, Zarzecka (1998) showed that Sencor + Fusilade did not affect cooking quality of potato tubers. 


\section{REFERENCES:}

A.O. A. C. (1980). Official Methods of Analysis, Association of Official Agricultural Chemists, bed., Washington, D.C.P.1018.

Arnold, R. N., Murray, M.W., Gregory, E.J., and Smeal, D. (1991).Weed Control in field potatoes. Agric. Experiment Station Research Report 723. College of Agric. and Home Economics.

Arora, A, Tomar, S. S., Gole, M. K. (2009). Yield and quality of potato as influenced by weed management practices and their residual study in soil. Agric. Sci. Digest, 29(2):39-41.

Channappagoudar, B. B., Biradar, N. R., Bharmagoudar, T. D., Koti, R. V. (2007). Crop weeds competition and chemical control of weeds in potato. Karnataka. of Agric. Sci., 20 (4):715-718.

Channappagoudar, B.B., Biradar, N. R., Bharamagoudar, T. D., Koti, R. V. (2008). Influence of herbicides on physiological and biophysical parameters in potato. Karnataka. of Agric. Sci., 21, 1:4-7.

Dinesh, K., R. Ezekiel, B. Sing and I. Ahmed (2005). Conversion table for specific gravity dry matter and starch content from under water weight of potatoes grown in North India plains. Potato J., 32 (1-2) : 79-84

Duncan, B. D. (1955). Multiple test range and multiple $F$ tests. Biometrics. 11-142.

El-Gamal, A. M. (1989). Increasing seed-sized tubers of cara potato by gibbrillic acid and some agricultural treatments. J. Agric. Sci., Mansoura Univ., 14(2): 699-706.

El-Mahy, S. A. (2005). Efficacy of some pre- and post-emergence herbicides in potato and tomato crops with reference to residues of fluazifop-butyl in tomato and bermudagrass plants. Bull. of Fac. of Agric., Cairo Univ. 56, 1:173-188.

Frito Lay Company (1999). Potato sending Manual. Operations quality system department. Leicester, United Kingdom

Gitsopoulos, T. K., Damalas, C. A., Georgoulas, I. (2014). Herbicide mixtures for control of water smartweed (Polygonum amphibium) and wild buckwheat (Polygonum convolvulus) in potato. Weed Techn. 28, 2:401407.

Haase, N.U. (2003). Estimation of dry matter and starch concentration in potatoes by determination of underwater weight and near infra red spectroscopy. Journal of potato research, Netherland, 46(3-4):117-127

Jackson, M.L. (1973). Soil Chemical Analysis. Prentice Hall Private, Ltd., New York

Jovovic, Z., Momirovic, N., Alovic, I., Stesevic, D. (2005). The effect of weed control mode on some more significant production traits of potato. Herbologia, 6: 1:75-84.

Kheraba, A. H., Shaban, S. A., Abdulla, A. M. (1991).Weed control studies on potato. II - Yield and quality. Egyptian Journal of Agrono.17-32.

Kumar, C. C., Shrivastava, G. K., Kumar, C. A., Dewangan, C. (2013). Effect of water management, weed and integrated nutrient management on yield of potato (Solanum tuberosum).Trends in Biosciences, 6:5:544-546.

Mircov, V. D., Alovic, I., Brocic, Z. (2006). Results of weed control in field potatoes. Herbologia, 7(1):3-7. 
Mukhopadhyay, S. K., Dhiman R., Chettri, M. (2002). Evaluation of Prometryn 50 WP as a herbicide in potato (Solanum tuberosum L.). Orissa Journal of Horticulture, 30:1:64-67.

Mukherjee, P. K., Rahaman, S., Maity, S. K., Sinha, B. (2012). Weed management practices in potato [Solanum tuberosum L.]. Journal of Crop and Weed,. 8:1:178-180.

Panghal, V. S., Nehra, B. K., Khurana, S. C., Singh, N. (2003). Effect of different herbicides and time of application on tuber yield and weed control efficiency in potato. of the Indian Potato Association, 30: 1/2:107-108.

Rana, M. C., Rana, S. S., Man Singh (2004). Influence of weed control and fertility levels on the productivity of seed potato under Lahaul valley conditions of Himachal Pradesh.Indian Journal of Weed Science, 37: 3/4:228-230.

Rashmi Yadav and Kumar, V. A. (2011). Bio-efficacy of herbicides against complex weed flora in potato (Solanum tuberosum) crop grown through mini plants. Indian Journal of Agric. Sci. 81: 4:386-388.

Salna, A. and Tyla, G.(1996). Studies on the effectiveness of Fusilade Super, Nabu, Targa, Zellek on couch-grass killing in potato stands. Lietuvos Zemdirbystes Instituto Mokslo Darbai, Zemdirbyste,. (54):83-96.

Snedecor, G.W. and Cochran, W.G. (1980). Statistical Methods. $6^{\text {th }}$ Ed., lowa State Univ. Press, Ames, USA.

Thomas K. G., Christos A. D. and I. Georgoulas. (2014). Herbicide mixtures for control of water smartweed (Polygonum amphibium) and wild buckwheat (Polygonum convolvulus) in Potato. Weed Techn., 28(2):401407.

Vincent, L. (2009). Tropical root and tuber [crops: cassava sweet potato, Yams and Aroids Publisher ISBN 978-1-84593-424-8.

Wettstein, D. (1957). Chlorophyll lethal under submikro-skopiche formwechsel der plastiden. Expt. Cell Res., 12:427-433.

Winigar, F.A. and ludwing J.W. (1974). Methoden der Qualitatsbeurteilung bei Kartoffeln Furden menschlichen konsum. J. Potato Research, 17:4 434465

Zarzecka, K. (1998). Assessment of different weed control systems on potato plantations: Part II. Effect of weed control systems on the height and quality of potato yield. Roczniki Nauk Rolniczych. Seria A, Produkcja Roslinna, 113, (1/2):179-186. 
الملخص العربى

تأثير بعض معاملات مكافحة الحشائش على محصول البطاطس

على على شرشر "و الحسانين الثربينى حسانين" و اميمة شلتوت" "و منى محمد يسرى" و احمد محمود الجمل"

" مركز البحوث الزراعية - المعمل المركزى لبحوث الحشائش - مصر

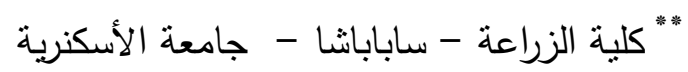

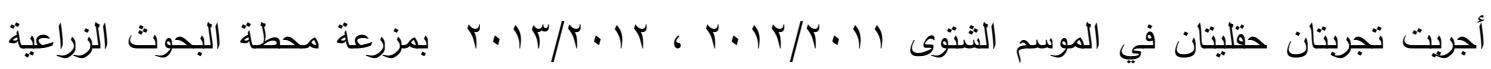

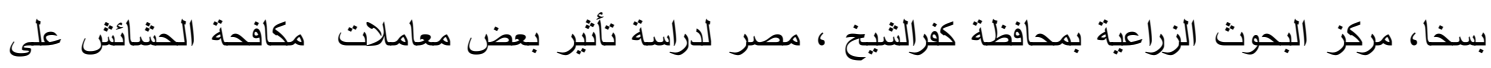

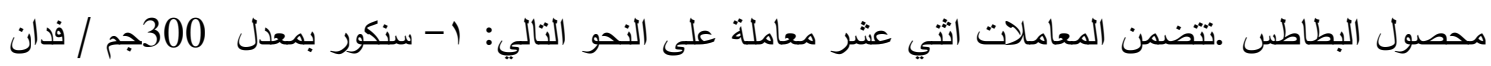

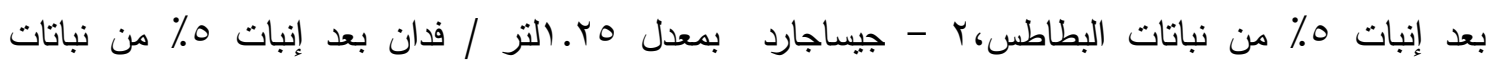

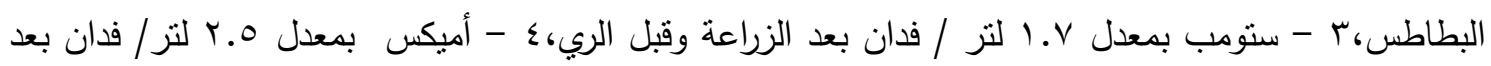

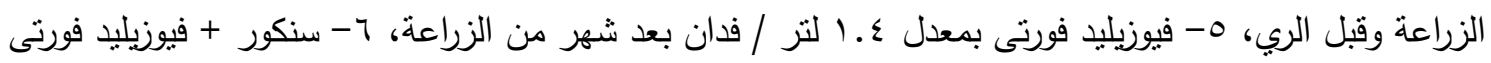

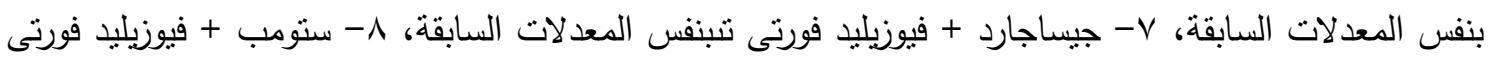

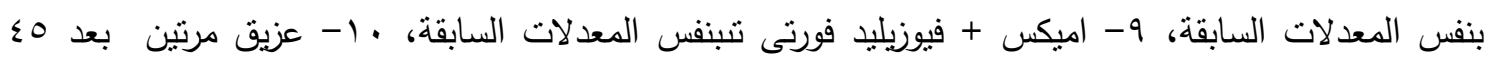

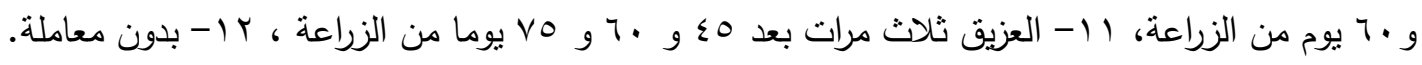

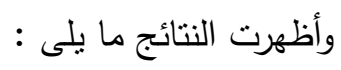

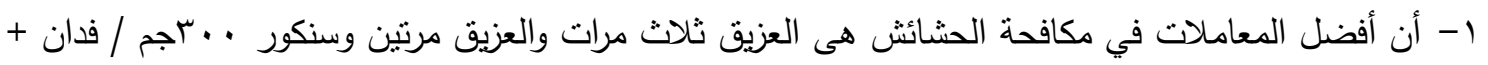
فيوزيليد فورتى ع. التز / فدان، حيث أعطت أعلى نسبة إبادة للحشائش الحولية.

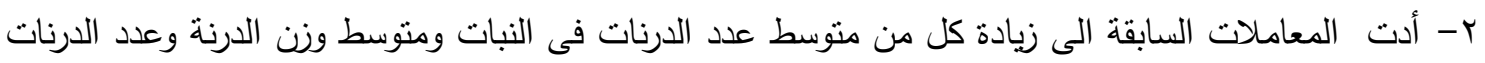

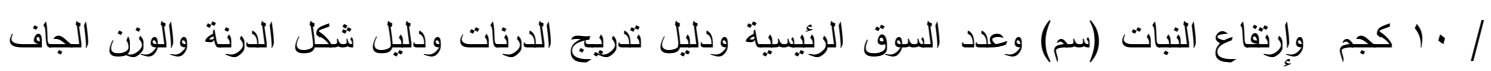
للارنة، نسبة النشا والكثافة النوعية مقارنة مع المعاملة الكنترول (بدون معاملة).

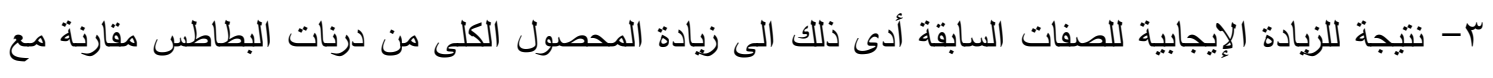
المعاملة الكنترول (بدون معاملة). أثنارت نتيجة البحث أن أفضل معاملة لمكافحة الحشائش المصاحبة لنباتات البطاطس هى على الترثيب العزيق

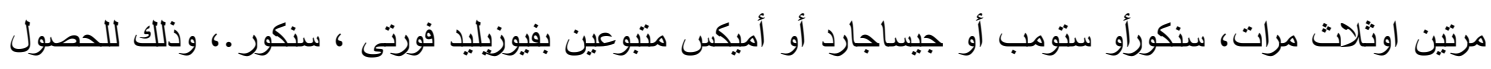

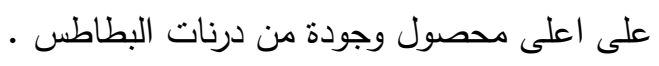

